\title{
Dermatobiosis in Panthera onca: first description and multinomial logistic regression to estimate and predict parasitism in captured wild animals
}

\author{
Dermatobiose em Panthera onca: primeira descrição e regressão \\ logística multinomial para estimar e prever o parasitismo em \\ animais selvagens capturados
}

\begin{abstract}
Joares Adenilson May-Junior1,2,3,4\# (1); Renata Fagundes-Moreira4*\# (1); Vinícius Baggio de Souza3 (1); Bruno Albuquerque de Almeida ${ }^{5}$; ; Mario B. Haberfeld ${ }^{1,6}$ (D); Leonardo R. Sartorelo ${ }^{1}$ (D); Lilian Elaine Ranpim ${ }^{1}$ (D); Carlos Eduardo Fragoso ${ }^{1}$ (1); João Fabio Soares ${ }^{4}$ (D)

${ }^{1}$ Associação Onçafari, São Paulo, SP, Brasil

2 Panthera Corporation, New York, NY, USA

${ }^{3}$ Universidade do Sul de Santa Catarina, Tubarão, SC, Brasil

${ }^{4}$ Laboratório de Protozoologia e Rickettsioses Vetoriais, Faculdade de Veterinária, Universidade Federal do Rio Grande do Sul, Porto Alegre, RS, Brasil

${ }^{5}$ Setor de Patologia Veterinária, Faculdade de Veterinária, Universidade Federal do Rio Grande do Sul, Porto Alegre, RS, Brasil

${ }^{6}$ Instituto SOS Pantanal, Campo Grande, MS, Brasil
\end{abstract}

\begin{abstract}
How to cite: May-Junior JA, Fagundes-Moreira R, Souza VB, Almeida BA, Haberfeld MB, Sartorelo LR, et al. Dermatobiosis in Panthera onca: first description and multinomial logistic regression to estimate and predict parasitism in captured wild animals. Braz J Vet Parasito/ 2021; 30(1): e023820. https://doi.org/10.1590/S1984-29612021003
\end{abstract}

\begin{abstract}
Dermatobia hominis is a parasite widely distributed in neotropical regions. The parasitic phase of the cycle is characterized by the formation of a subcutaneous nodule in the host, which can promote infestation by other dipterans and skin infections. The aim of this report is to register parasitism by $D$. hominis in free-ranging Panthera onca captured in the Brazilian wetland and to determine significant biological and meteorological factors that are likely to influence the presence of larval parasitism in captured wild jaguars. Between 2011 to 2020, 34 jaguars were captured and examined manually by searching for lesions characteristic of myiasis. By manual compression in the subcutaneous nodules, larvae morphologically identified as $D$. hominis (first and third instars) were collected from 13 jaguars. A multinomial logistic regression showed that adult jaguars had 16.49 -fold higher odds of being parasitized than subadults. Thus, jaguars captured in the season of July-September have 34.01- and 11.42-fold higher odds of being parasitized compared to the seasons of October-December and April-June, respectively, which is associated with high total monthly precipitation in the previous season. The present study is the first to describe parasitism by $D$. hominis larvae in jaguars.
\end{abstract}

Keywords: Panthera onca, ectoparasite, botfly, dermatobiosis, conservation.

\section{Resumo}

Dermatobia hominis é um parasito amplamente distribuído nas regiões neotropicais. A fase parasitária do ciclo é caracterizada pela formação de um nódulo subcutâneo no hospedeiro, que pode promover infestação por outros dípteros e infecções cutâneas. $\mathrm{O}$ objetivo deste relato é registrar o parasitismo por $D$. hominis em Panthera onca de vida livre, capturado no pantanal brasileiro e determinar fatores biológicos e meteorológicos significativos que podem influenciar a presença de parasitismo larval em onças-pintadas selvagens capturadas. Entre 2011 e 2020, 34 onças-pintadas foram capturadas e examinadas manualmente em busca de lesões características de miíase. Por compressão manual nos nódulos subcutâneos, larvas classificadas morfologicamente como $D$. hominis

Received October 12, 2020. Accepted January 12, 2021.

Financial support: This study was supported by the Conselho Nacional de Desenvolvimento Científico e Tecnológico (CNPq), Coordenação de Aperfeiçoamento de Pessoal de Nível Superior - Brasil (CAPES) Finance code 001 and Fundação de Amparo à Pesquisa do Estado do Rio Grande do Sul (FAPERGS), Project FAPERGS “Pesquisa de patógenos emergentes em felídeos Neotropicais como ferramenta de auxílio à conservação" (19/25510001842-8).

*Corresponding author: Renata Fagundes-Moreira. E-mail: renata.fagundes.mm@gmail.com \#Co-first authors. 
(primeiro e terceiro instares) foram coletadas de 13 onças-pintadas. Uma regressão logística multinomial mostrou que onças-pintadas adultas tinham chances 16,49 vezes maiores de serem parasitadas do que subadultos. Assim, onças-pintadas capturadas na temporada de julho a setembro têm probabilidade 34,01 e 11,42 vezes maior de serem parasitadas em comparação com as temporadas de outubro a dezembro e de abril a junho, respectivamente, o que está associado à alta precipitação total mensal na temporada anterior. O presente estudo é o primeiro a descrever parasitismo por larvas de $D$. hominis em onças-pintadas.

Palavras-chaves: Panthera onca, ectoparasito, berne, dermatobiose, conservação.

\section{Introduction}

Dermatobia hominis (Linnaeus Jr., 1781) (Diptera: Oestridae) is a dipteran from the Oestridae family widely distributed in the neotropical region from southern Mexico to northern Argentina (Guimarães \& Papavero, 1966). This ectoparasite develops a larval shape in the host's subcutaneous tissue and cause a primary furuncular myiasis, which is characterized by the presence of a subcutaneous nodule (Sancho, 1988).

It occurs in several domestic and livestock animals, and is of particular importance due to economic losses in relation to livestock, which reach US $\$ 0.38$ billion per year in Brazil (Grisi et al., 2014). Furthermore, it is a dermatozoonosis (Burns, 2010), with several records mainly in tourists from European and Asian countries visiting South America, and in indigenous people (Denion et al., 2004).

Although several studies reported the presence of $D$. hominis in wild animals, there are no concrete reports based on specific morphological identification or case reports in specific wild hosts, but only general references in the literature. Unlike other myiases that are reported in several species of wild animals, such as caused by insects belonging to the genera Cochliomyia in Didelphis marsupialis (Reis et al., 2008), Galictis cuja (Figueiredo et al., 2010) and Chrysocyon brachyurus (Cansi et al., 2011); Chrysomya in Taurotragus oryx (Obanda et al., 2013) and Rusa unicolor (Radhakrishnan et al., 2012); and Lucilia in Gazella subgutturosa (Gökçen \& Sevgili, 2007), Ramphocelus dimidiatus (Bermúdez et al., 2010) and D. albiventris (Cansi \& Bonorino, 2011).

The jaguar (Panthera onca) is the largest feline in the Americas, being vulnerable to extinction due mainly to poaching and habitat loss (Morato et al., 2013). Therefore, every parasitic or infectious agent with the potential to affect populations of this species deserves considerable study. In view of that, we describe here the parasitism by $D$. hominis in free-ranging jaguars and a multinomial logistic regression to estimate and predict parasitism in captured wild animals.

\section{Materials and Methods}

\section{Study area}

The present study was carried out in the Brazilian wetland region (Pantanal biome), located in the State of Mato Grosso do Sul. The captures were performed at the Caiman Ecological Refuge (CER), a privately-owned farm/ natural reserve dedicated to wildlife tourism and cattle ranch. The period of captures was divided in January to March, April to June, July to September and October to December. Meteorological factors studied included monthly precipitation totals retrieved from manual measurement in the CER. Thus, access to the automatic station of the Instituto Nacional de Meteorologia (INMET, Brazil) in Miranda (code: A722, Latitude: -20.39555555 Longitude: $-56.43166666)$ provided the mean monthly temperatures.

\section{Captures}

The captures and animal handling were performed following the ethical procedures of the Chico Mendes Institute for Biodiversity Conservation (ICMBio; permit \#42093-1) and Research Comitte UFRGS (COMPESQ UFRGS; \#38198).

Camera traps were used to check areas for jaguar movement, where foot snare traps were set up for the physical restraint of individuals (Frank et al., 2003). The captures occurred between October 2011 and June 2020. Once contained in the trap, they were sedated with a $5 \mathrm{mg} / \mathrm{kg}$ combination of tiletamine-zolazepam intramuscularly (Poole et al., 1993; Onuma et al., 2015) by $\mathrm{CO}_{2}$ rifle dart in order to place the GPS collar and to collect biological material and biometric information.

\section{Physical examination}

The physical evaluation was carried out by professionals experienced in practical approaches to the evaluation of wild carnivores. Captured individuals received a radio telemetry (VHS) necklace and a unique identification, thus 
enabling identification of recaptured animals. A general assessment regarding weight (kg), body condition and tooth wear to define age was performed.

An in loco observation was carried out, looking for subcutaneous nodules and lesions suggestive of myiasis in all body parts, cavities and orifices of individuals. After detection, the removal of larvae was performed through manual compression of the subcutaneous nodules. These larvae were conserved directly in $70 \%$ ethanol.

\section{Morphological identification}

The larvae of $D$. hominis were morphologically identified according to Guimarães \& Papavero (1999) and Berne (2009). The larvae of C. hominivorax were identified according to Hall (1948). The D. hominis stages were identified according to Neiva (1914). The larvae were deposited in the Vector's Collection of the Laboratório de Protozoologia e Rickettsioses Vetoriais of Federal University of Rio Grande do Sul, under the registration numbers 02/2019 (third instar larva) and 01/2020 (first instar larva).

\section{Statistics}

A model was estimated to determine significant biological and meteorological characteristics that were likely to influence the presence of larval parasitism in captured wild $P$. onca. Jaguars lacking larval parasitism were considered the reference category. The factors included gender, age [subadult (up to 18 months old), adult (18 months old from to 10 years old) and old (over 10 years old)], capture season (January-March, April-June, July-September and October-December) and year. Covariates consisted of total precipitation $(\mathrm{mm})$ and mean temperature $\left({ }^{\circ} \mathrm{C}\right)$ in the month of capture. Multi-collinearity was tested using a linear model, and predictors with variance inflated factor (VIF) of $\geq 2$ were excluded in a backward elimination. Multiple logistic regression used backward steps to define the final model. Model fit assessment used Pearson chi-square statistics, McFadden and Nagelkerke pseudo- $\mathrm{R}^{2}$. Tenyear (2011-2020) historic mean monthly temperatures and monthly precipitation totals were compared between different seasons by Kruskal-Wallis test, plus pairwise comparison with Bonferroni correction for multiple tests. The level of significance used as a criterion for the rejection of the null hypothesis was $5 \%(p \leq 0.05)$ and statistical analyses used IBM SPSS Statistics 22.0 software.

\section{Results and Discussion}

In total, 34 jaguars were captured between 2011 to 2020; 22 (64.70\%) of these were recaptured, totaling 56 capture events. In the individual identification, 21 females and 13 males were captured and subdivided into the three age groups previously mentioned: subadult $(n=10)$, adult $(n=23)$, and old $(n=1)$.

In 13 captures, larvae of approximately $20-30 \mathrm{~mm}$ were collected from different parts of the individuals' bodies, such as head, neck, upper lip, thorax and left anterior limb (Figure 1) (Table 1). The collected larvae were identified as belonging to the species $D$. hominis in the first and third instars due to their set of morphological characteristics (Figure 2).
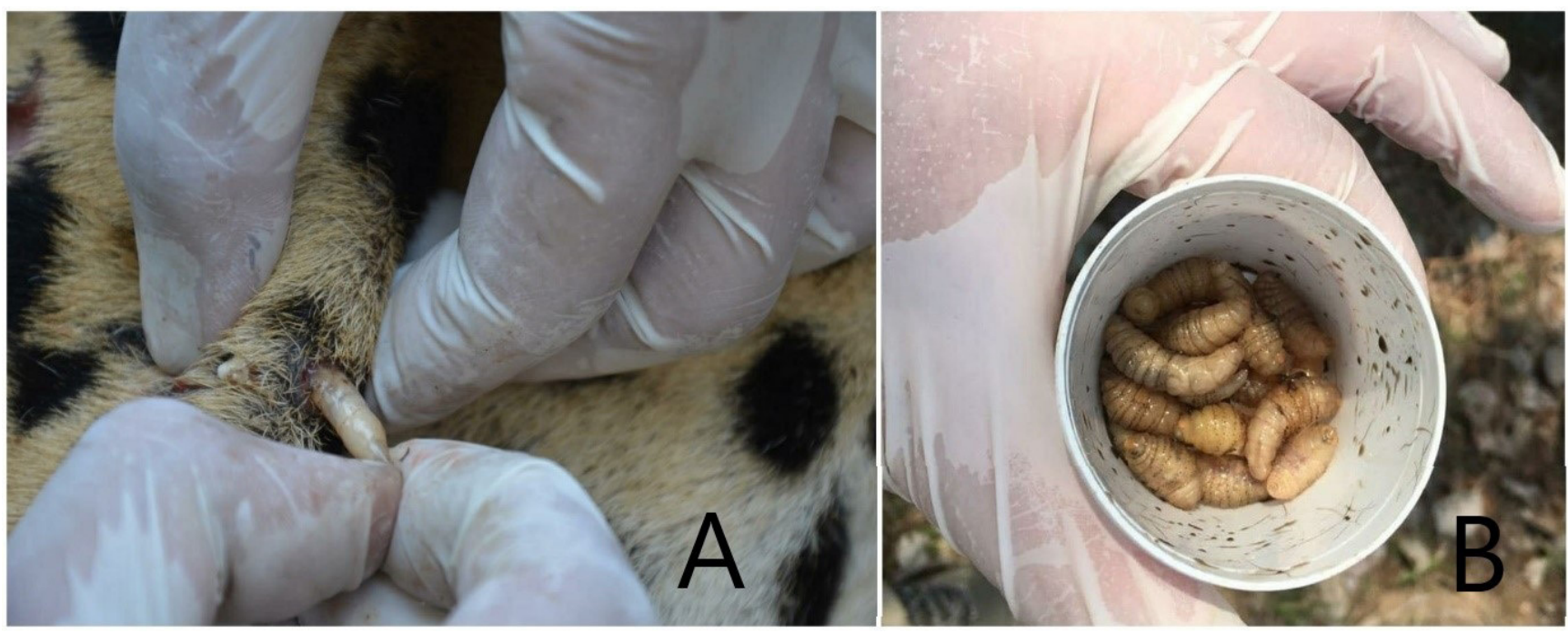

Figure 1. A: Removal of a larva of Dermatobia hominis (Linnaeus Jr., 1781) (Diptera: Oestridae) of an individual of jaguar (Panthera onca) captured in the present study. B: Larvae of $D$. hominis collected from jaguars. 
Table 1. Respective data on gender, age, capture date and infestation local of Dermatobia hominis (Linnaeus Jr., 1781) (Diptera: Oestridae) in jaguars.

\begin{tabular}{ccccc}
\hline Capture identification & Age & Gender & Capture date & Infestation local \\
\hline PO24 & Adult & Male & September, 2016 & Head, neck \\
PO30 & Adult & Female & April, 2017 & Head, neck \\
PO31 & Adult & Male & April, 2017 & Head, neck \\
PO24a & Adult & Male & July, 2017 & Head, neck \\
PO34 & Adult & Male & July, 2017 & Head, neck \\
PO36 & Subadult & Female & September, 2017 & Head, neck \\
PO37 & Adult & Male & September, 2017 & Head, neck \\
PO38 & Old & Female & September, 2017 & Head, neck \\
PO39 & Adult & Male & March, 2018 & Head, neck \\
PO24 ${ }^{\text {a }}$ & Adult & Male & March, 2018 & Head, neck, upper lip, \\
& Adult & thorax & Head, neck \\
PO44 & Adult & Female & September, 2018 & Head, neck, left anterior \\
PO53 & Female & December, 2019 & limb \\
PO56 & Adult & Male & June, 2020 & Thorax \\
\hline
\end{tabular}

a Recaptured jaguar.
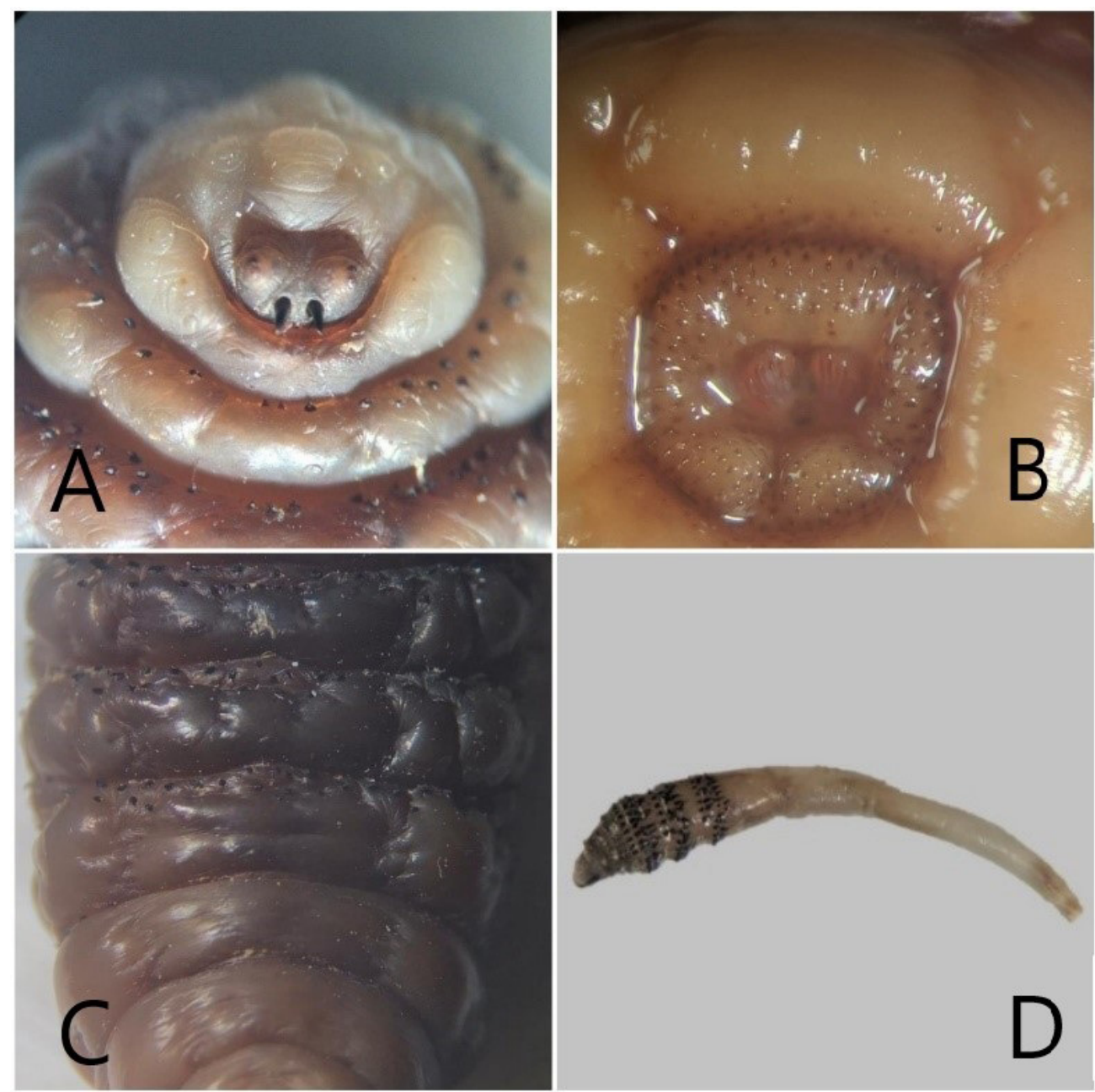

Figure 2. Important morphological structures for the morphological identification of Dermatobia hominis (Linnaeus Jr., 1781) (Diptera: Oestridae). In " $\mathrm{A}$ " two hooks at the mouth opening. In " $\mathrm{B}$ " two respiratory spiracles. In " $\mathrm{C}$ " and " $\mathrm{D}$ " spines covering the thoracic and abdominal portions of the larva's body. In " $\mathrm{C}$ " larva of the third instar and in " $\mathrm{D}$ " larva of the first instar. 
Due to the impossibility of sending live larvae to complete the cycle under controlled laboratory conditions, during removal and storage, the larvae acquired an excessively dark color (Figure 3). In some cases, the presence of Cochliomyia hominivorax larvae were observed parasitizing the jaguars.

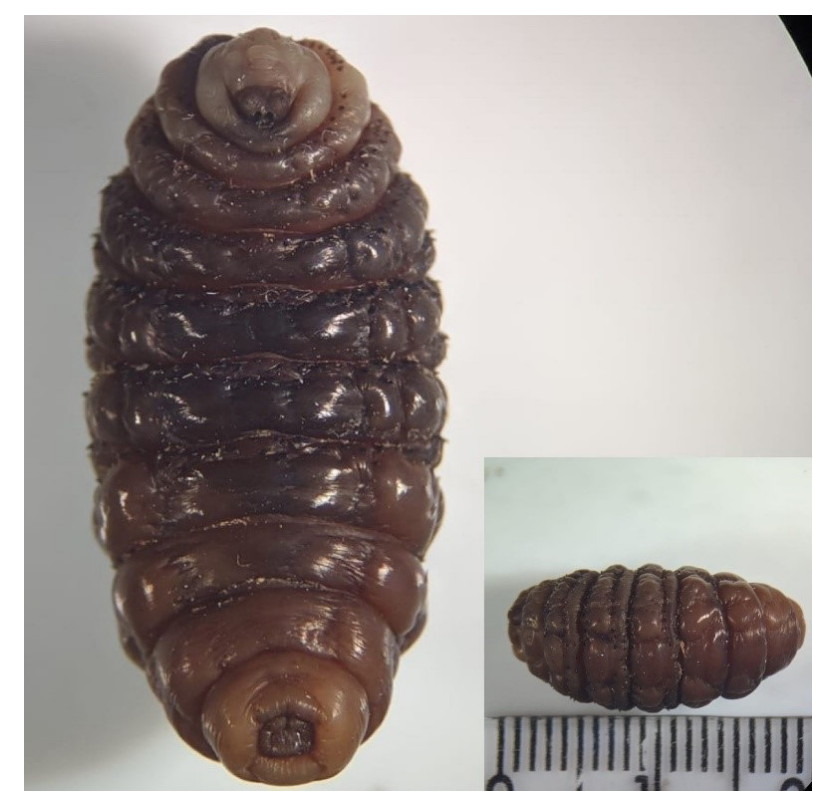

Figure 3. Dermatobia hominis' (Linnaeus Jr., 1781) (Diptera: Oestridae) larva of the present study showing too dark a color due to the technique of removal and storage.

No factors are excluded when checking for multicollinearity and $p$ value of backward pairwise exclusion is show in Table 2. Age showed a significant association to larval parasitism.

Adult captured jaguars had 16.49-fold higher odds the odds of being parasitized compared to subadults while controlling for season (Table 3).

While controlling for age, jaguars captured in the season of July-September had 34.01- and 11.42-fold higher odds of being parasitized compared to those captured in October-December and April-June, respectively (Table 3). The season of July-September had the lowest monthly precipitation totals (Figure 4) (Table 4). An increase in precipitation totals during previous months, rather than in the current month, is associated with the presence of $D$. hominis larval parasitism in cattle (Brito \& Moya Borja, 2000). In our study, the months April-June showed a higher precipitation total than July-September, which can favor posterior observation of larval parasitism in the next season, which are probably associated with larval parasitism ranging from 34 to 78 days (Neiva \& Gomes, 1917; Villalobos et al., 2016). The final model using capture months and jaguar age are acceptable (Table 4).

In our study, the mean monthly temperature was excluded from the model; in addition, April-June and JulySeptember temperatures did not differ and could not help explain the parasitism association to specific months. Mean monthly temperatures equal to or higher than $25^{\circ} \mathrm{C}$ are associated with increased parasitism in slaughtered cattle (Brito \& Moya Borja, 2000). Lack of association with temperature could be linked with the method of jaguar sampling, which follows the convenience of individual entrapment and which can differ from the systematic monthly observation of several herds in a slaughterhouse.

Health assessments in wild animals are important in the context of the epidemiology of ectoparasites, zoonosis and vector-borne diseases. This first assessment in jaguars is also important to the touristic region's public health, considering that dermatosis is widely observed in travelers of other continents (Caumes et al., 1995).

A possible visual record of infestation was observed by camera traps according to the thesis of Harmsen (2006), in which he suggested that swelling and scarring on the skin of individuals of $P$. onca observed in his study arose from the presence of $D$. hominis. In another thesis, Furtado (2010) observed parasitism by dipteran larvae in jaguars from Pantanal and Amazon biomes in Brazil; however, in both reports there was no morphological evaluation of the larvae (unpublished data), unlike the present study, which allowed the confirmation of the species involved in the parasitism. 

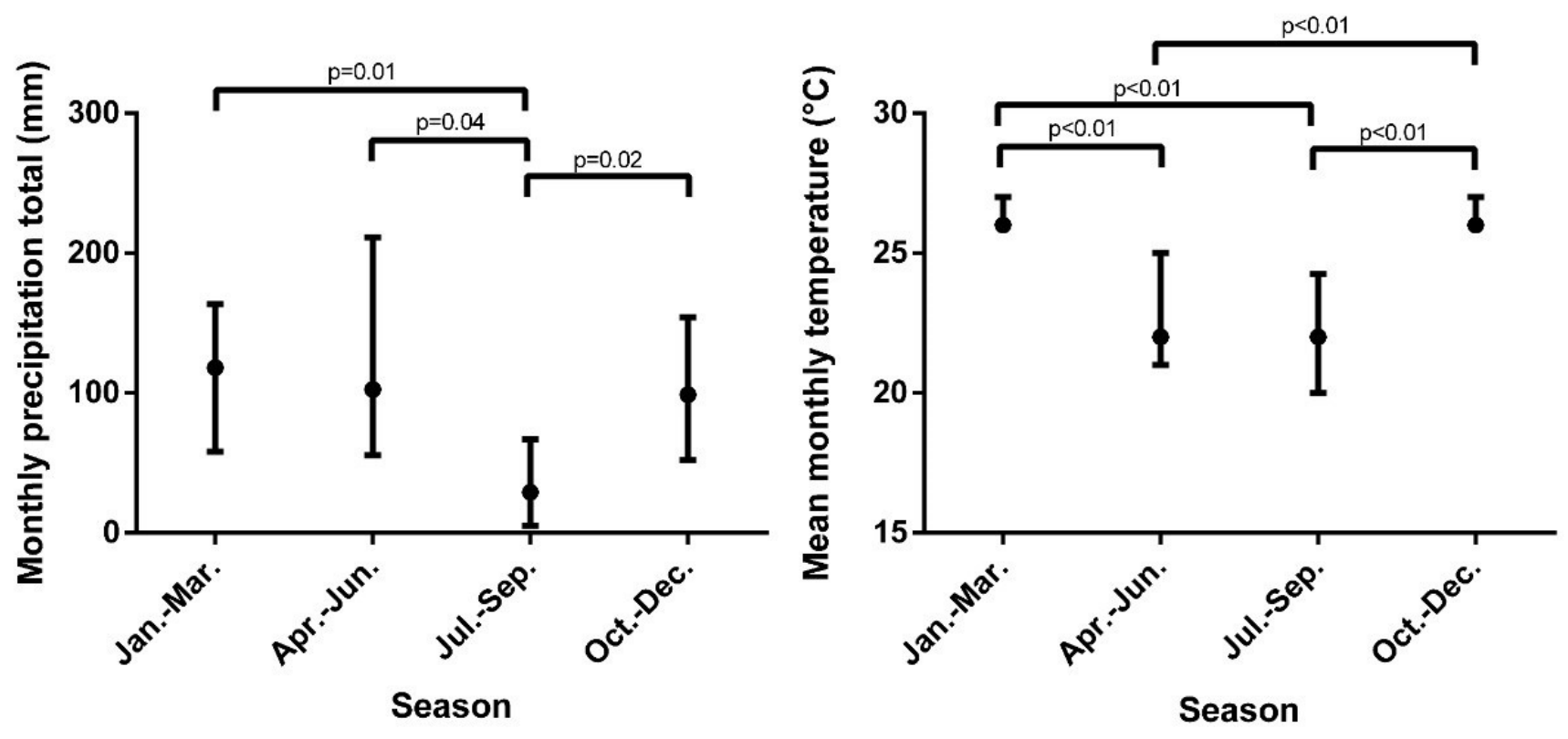

Figure 4. Median (interquartile range: $25-75 \%$ ) of historic monthly precipitation total and mean monthly temperature according to the season (2011-2020).

Table 2. Factors and covariates descriptive statistics and backward stepwise $p$ value.

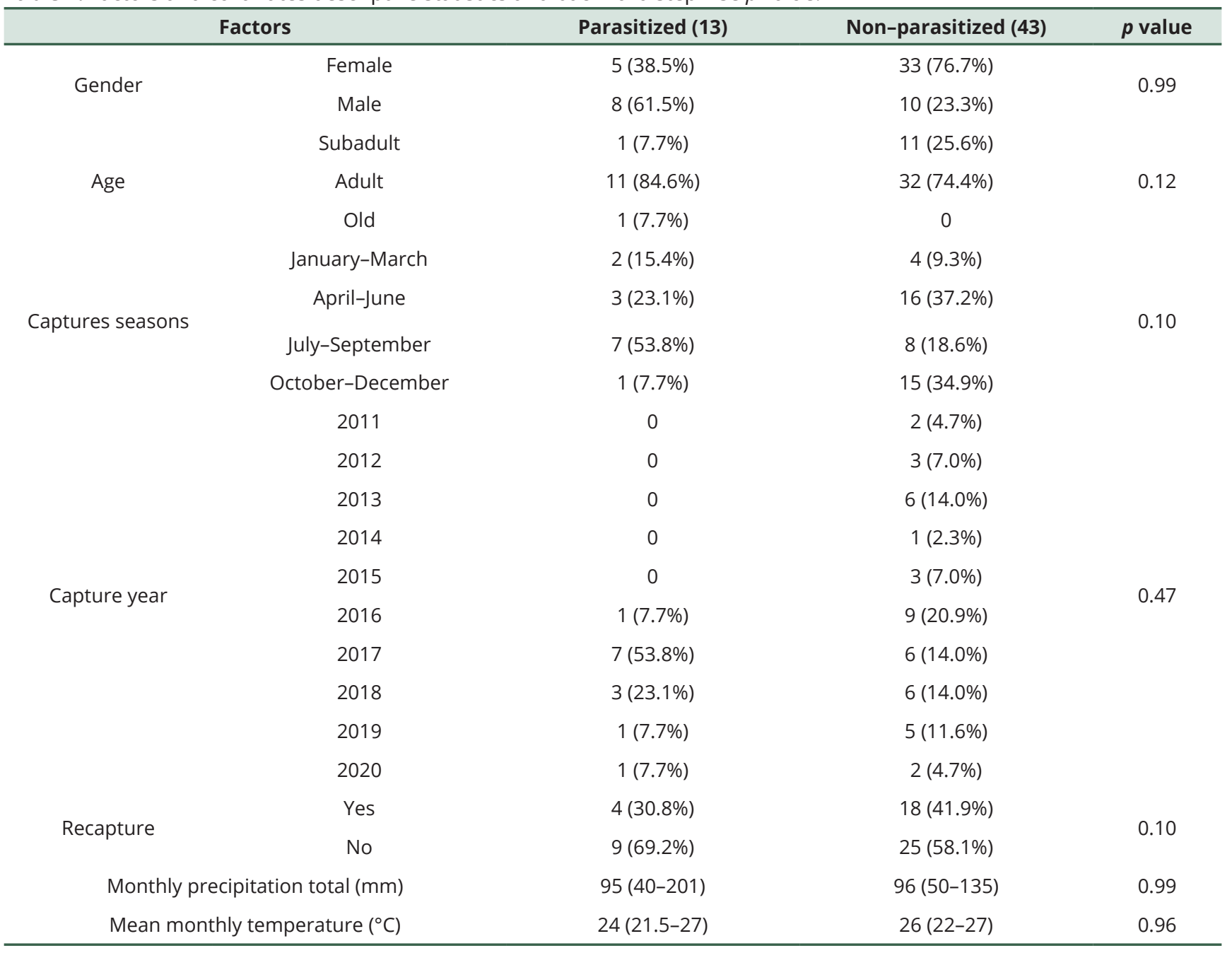


Table 3. Parasitized Panthera onca associated factor in multinomial logistic regression analysis.

\begin{tabular}{ccccc}
\hline & Factor & b & Adjusted OR (95\% C.I.) & p value \\
\hline \multirow{2}{*}{ Age } & Adult vs. subadult & 2.803 & $16.49(1.22-222.62)$ & 0.02 \\
Seasons & July-September vs. October-December & 3.526 & $34.01(2.54-454.90)$ & 0.01 \\
& July-September vs. January-March & 1.645 & $5.18(0.49-54.34)$ & 0.17 \\
& July-September vs. April-June & 2.435 & $11.42(1.49-87.11)$ & 0.02 \\
\hline
\end{tabular}

Table 4. Assessment of final model.

\begin{tabular}{cc}
\hline Tests & Result \\
\hline Pearson chi-square statistic $(p$ value) & 0.97 \\
Nagelkerke (pseudo R $\left.{ }^{2}\right)$ & 0.42 \\
McFadden (pseudo R $\left.{ }^{2}\right)$ & 0.30 \\
\hline
\end{tabular}

Jaguars have wide home ranges of between 38 and $68 \mathrm{~km}^{2}$ (Azevedo \& Murray, 2007); these animals can act in the dispersion of $D$. hominis. In addition, $D$. hominis is a dipteran native to the neotropical region (Guimarães \& Papavero, 1999), and a knowledge of its natural hosts that maintain its lifecycle is essential in understanding its epidemiology and preventing cases of dermatobiosis.

From another perspective, parasitism by $D$. hominis in cattle has been an important cause of economic losses in Brazilian production. It is estimated that 100 million cattle are exposed to parasitism by this dipteran (Grisi et al., 2014). Knowing this, it can be considered that parasitism by $D$. hominis of jaguars that live near livestock areas can be aggravated by the extensive herds of cattle in the region.

Dermatobiosis in endangered species populations is an aggravating factor, as the lesions caused by $D$. hominis larvae can promote the development of other myiases, such as by C. hominivorax larvae (Grisi et al., 2014) as noted in the present study, leading to the development of injuries to jaguars that may impair their hunting habits, the defense of their territory, or even the death of individuals in an already vulnerable population.

\section{Acknowledgments}

The authors are very grateful to all collaborators and employees of the Refúgio Ecológico Caiman, Associação Onçafari, Zoetis Brasil and Global Insular Conservation Society for their activities in favor of the conservation of the jaguar in Brazil. We thank the Professor Silvia Gonzalez Monteiro and Margareth Maria de Carvalho Queiroz for the technical assistance.

\section{References}

Azevedo FCC, Murray DL. Spatial organization and food habits of jaguars (Panthera onca) in a floodplain forest. Biol Conserv 2007;137(3):391-402. https://doi.org/10.1016/j.biocon.2007.02.022

Bermúdez CSE, Buenaventura RE, Couri M, Miranda RJ, Herrera JM. Mixed myiasis by Philornis glaucinis (Diptera: Muscidae), Sarcodexia lambens (Diptera: Sarcophagidae) and Lucilia eximia (Diptera: Calliphoridae) in Ramphocelus dimidiatus (Aves: Thraupidae) chicks in Panama. Bol SEA 2010; 47: 445-446.

Berne MEA. Miíases. In: Cavalcante ACR, Vieira LS, Chagas ACS, Molento MB. Doenças parasitárias de caprinos e ovinos: epidemiologia e controle. 1st ed. Brasília: Embrapa Informação Tecnológica; 2009.

Brito LG, Moya Borja GE. Flutuação sazonal de Dermatobia hominis em peles bovinas oriundas de matadouro. Pesq Vet Bras 2000; 20(4): 151-154. http://dx.doi.org/10.1590/S0100-736X2000000400004.

Burns DA. Diseases caused by Arthropods and other noxious animals. In: Burns T, Breathnach S, Cox N, Griffiths C. Rook's textbook of dermatology. 8th ed. Oxford: Wiley Blackwell; 2010. p. 8-11. http://dx.doi.org/10.1002/9781444317633.ch38. 
Cansi ER, Bonorino R, Ataíde HS, Pujol-Luz JR. Myiasis by Screw Worm Cochliomyia hominivorax (Coquerel) (Diptera: Calliphoridae) in a Wild Maned Wolf Chrysocyon brachyurus (Mammalia: Canidae), in Brasília, Brazil. Neotrop Entomo/ 2011; 40(1): 150-151. http:// dx.doi.org/10.1590/S1519-566X2011000100025. PMid:21437499.

Cansi ER, Bonorino R. Miíase por Lucilia eximia (Diptera: Calliphoridae) em Didelphis albiventris (Mammalia: Didelphidae) no Brasil Central. Entomol Brasilis 2011;4(3): 150-151. http://dx.doi.org/10.12741/ebrasilis.v4i3.160.

Caumes E, Carrière J, Guermonprez G, Bricaire F, Danis M, Gentilini M. Dermatoses associated with travel to tropical countries: a prospective study of the diagnosis and management of 269 patients presenting to a tropical disease unit. Arch Clin Infect Dis 1995; 20(3): 542-548. http://dx.doi.org/10.1093/clinids/20.3.542. PMid:7756473.

Denion E, Dalens PH, Couppié P, Aznar C, Sainte-Marie D, Carme B, et al. External ophthalmomyiasis caused by Dermatobia hominis. A retrospective study of nine cases and a review of the literature. Acta Ophthalmo/ Scand 2004; 82(5): 576-584. http:// dx.doi.org/10.1111/j.1600-0420.2004.00315.x. PMid:15453857.

Figueiredo MA, Santos ACG, Guerra RMSNC. Ectoparasitos de animais silvestres no Maranhão. Pesq Vet Bras 2010; 30(11): 988990. http://dx.doi.org/10.1590/S0100-736X2010001100013.

Frank L, Simpson D, Woodroffe R. Foot snares: an effective method for capturing African lions. Wildl Soc Bull 2003; 31 (1): $309-314$.

Furtado MM. Estudo epidemiológico de patógenos circulantes nas populações de onça-pintada e animais domésticos em áreas preservadas de três biomas brasileiros: Cerrado, Pantanal e Amazônia [tese]. São Paulo: Universidade de São Paulo; 2010.

Gökçen A, Sevgili M. Türkiye'de bir ceylanda (Gazella subgutturosa) kutanöz miyaz vakası. Atatürk Üniv Vet Bilim Derg 2007; 2(3): 96-98.

Grisi L, Leite RC, Martins JRS, Barros ATM, Andreotti R, Cançado PHD, et al. Reassessment of the potential economic impact of cattle parasites in Brazil. Rev Bras Parasitol Vet 2014; 23(2): 150-156. http://dx.doi.org/10.1590/S1984-29612014042. PMid:25054492.

Guimarães JH, Papavero N. A tentative annotated bibliography of Dermatobia hominis (Linnaeus, Jr.) (Diptera, Cuterebridae). Arq Zool São Paulo 1966; 14(4): 223-294.

Guimarães JH, Papavero N. Myiasis in man and animals in the Neotropical region. Bibliographic database. São Paulo: FAPESP/ Editora Plêiade; 1999.

Hall DG. The blowflies of North America. Annapolis: Thomas Say Foundation; 1948.

Harmsen BJ. The use of camera traps for estimating abundance and studying the ecology of jaguars (Panthera onca) [Thesis]. Southampton: University of Southampton; 2006.

Morato RG, Beisiegel BM, Ramalho EE, Campos CBD, Boulhosa RLP. Avaliação do risco de extinção da Onça-Pintada Panthera onca (Linnaeus, 1758) no Brasil. BioBrasil 2013; 3(1): 122-132.

Neiva A. Informações sobre o berne. Mem Inst Oswaldo Cruz 1914; 6(3): 206-211. http://dx.doi.org/10.1590/S007402761914000300007.

Neiva A, Gomes JF. Biologia da mosca do berne (Dermatobia hominis) observada em todas as suas phases. An Paul Med Cir 1917; 8(9): 197-209.

Obanda V, Ndambiri EM, Kingori E, Gakuya F, Lwande OW, Alasaad S. Traumatic myiasis in free-ranging eland, reported from Kenya. Parasit Vectors 2013; 6(89):1-5. https://doi.org/10.1186/1756-3305-6-89.

Onuma SSM, Kantek DLZ, Crawshaw PG Jr, Morato RG, May-Junior JA, Morais ZM, et al. Detection of Leptospira spp. and Brucella abortus antibodies in free-living jaguars (Panthera onca) in two protected areas of Northern Pantanal, Brazil. Rev Inst Med Trop São Paulo 2015; 57(2): 177-180. http://dx.doi.org/10.1590/S0036-46652015000200014. PMid:25923900.

Poole KG, Mowat G, Slough BG. Chemical immobilization of lynx. Wildl Soc Bull 1993; 21(2): 136-140.

Radhakrishnan S, Gopalan AK, Ravindran R, Rajagopal K, Sooryadas S, Promod K. First record of Chrysomya albiceps Wiedemann, 1819 (Diptera: Calliphoridae) maggots from a sambar deer (Rusa unicolor) in Kerala, South India. J Parasit Dis 2012; 36(2): 280282. http://dx.doi.org/10.1007/s12639-012-0110-7. PMid:24082544.

Reis FS, Barros MC, Fraga EC, Penha TA, Teixeira WC, Santos ACG, et al. Ectoparasitos de pequenos mamíferos silvestres de áreas adjacentes ao rio Itapecuru e área de preservação ambiental do Inhamum, estado do Maranhão, Brasil. Rev Bras Parasitol Vet 2008; 17(Suppl. 1): 69-74. PMid:20059819.

Sancho E. Dermatobia, the neotropical warble fly. Parasitol Today 1988; 4(9): 242-246. http://dx.doi.org/10.1016/01694758(88)90138-X. PMid:15463112.

Villalobos G, Vega-Memije ME, Maravilla P, Martinez-Hernandez F. Myiasis caused by Dermatobia hominis: countries with increased risk for travelers going to neotropic areas. Int J Dermato/ 2016; 55(10): 1060-1068. http://dx.doi.org/10.1111/ijd.13302. PMid:27126902. 